\title{
Genetic heterogeneity in tuberous sclerosis: phenotypic correlations
}

\author{
I M Winship, J M Connor, P H Beighton
}

\begin{abstract}
There is increasing evidence for genetic heterogeneity in tuberous sclerosis (TSC) on the basis of linkage analysis in affected kindreds. We have performed a detailed assessment of an affected South African family in which there is no evidence of linkage to chromosome 9 markers. The affected persons have atypical clinical features, namely prominent nuchal skin tags, a confetti pattern of hypopigmentation of the skin of the lower legs, and absence of ungual fibromata. Further investigation of these unusual phenotypic features is warranted in order to determine whether these lesions are con-
\end{abstract}

MRC Unit for Inherited Skeletal Disorders, Department of Human Genetics, University of Cape Town Medical School, Observatory 7925, South Africa.

I $M$ Winship, P H Beighton

Department of Medical Genetics, Glasgow University, Duncan Guthrie Institute, Glasgow.

J M Connor

Correspondence to $\mathrm{Dr}$ Winship.

Received for publication 2 October 1989.

Revised version accepted for publication 31 January 1990. sistently present in families in whom the gene for TSC is not on $9 \mathrm{q} 34$. We conclude that confetti depigmentation and nuchal skin tags may be clinical pointers to an alternative locus for TSC.

Tuberous sclerosis (TSC) is inherited as an autosomal dominant trait and is characterised by multisystem hamartosis. The areas of predilection are the skin, central nervous system, kidneys, and heart, while other organs are less frequently affected. ${ }^{1}$ Certain skin lesions are pathognomonic of TSC (adenoma sebaceum, periungual fibromata, shagreen patches, fibrous facial plaques). Other skin changes may be suggestive (ash leaf macules) or compatible with the diagnosis of TSC in the appropriate clinical setting (café au lait macules, poliosis, guttate hypopigmentation, fibromas, fibrous skin tags).

Linkage analysis initially showed a locus for TSC on $9 \mathrm{q} .{ }^{2}$ In particular, Sampson $\mathrm{et}_{\mathrm{al}} \mathrm{l}^{3}$ reported positive linkage in seven out of eight families studied (lod score $6 \cdot 1$ ) with the Abelson oncogene (9q34). Subsequent investigations have indicated greater heterogeneity on the basis of linkage data with a probable second locus on $11 \mathrm{q} .{ }^{4}$ We have now undertaken

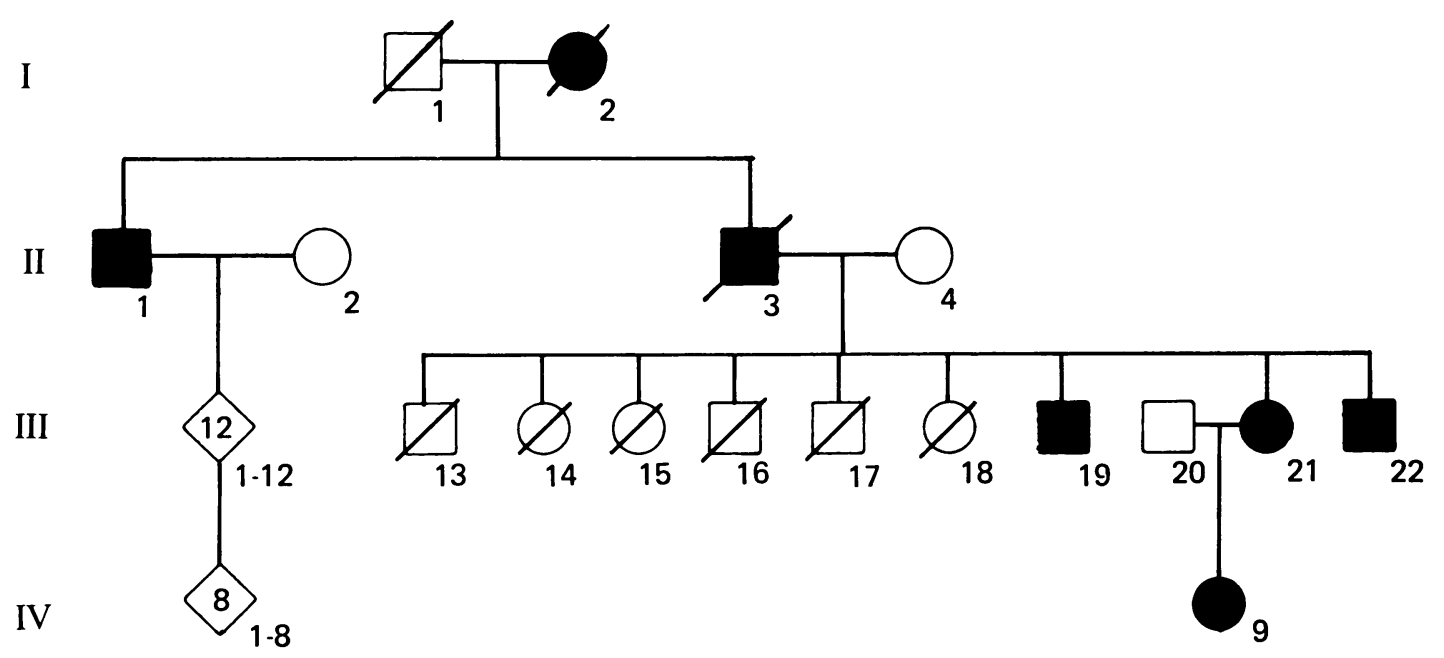

Figure 1 A pedigree of the affected family. 


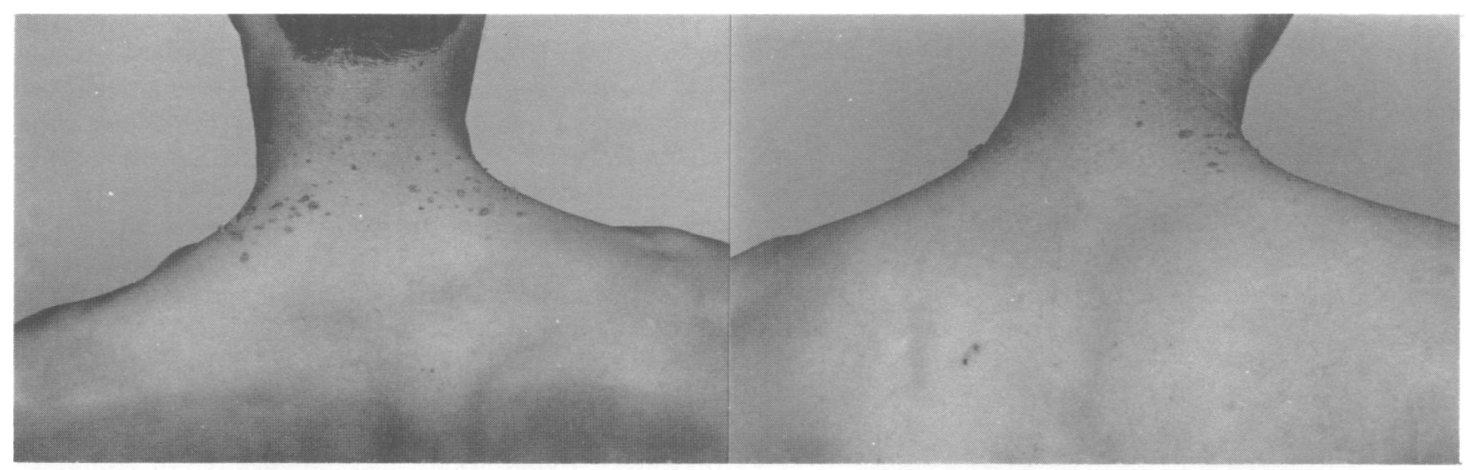

(a)

(b)

Figure 2 Multiple acrochordons (skin tags) at the base of the neck of (a) patient III 19 and (b) patient III 22.

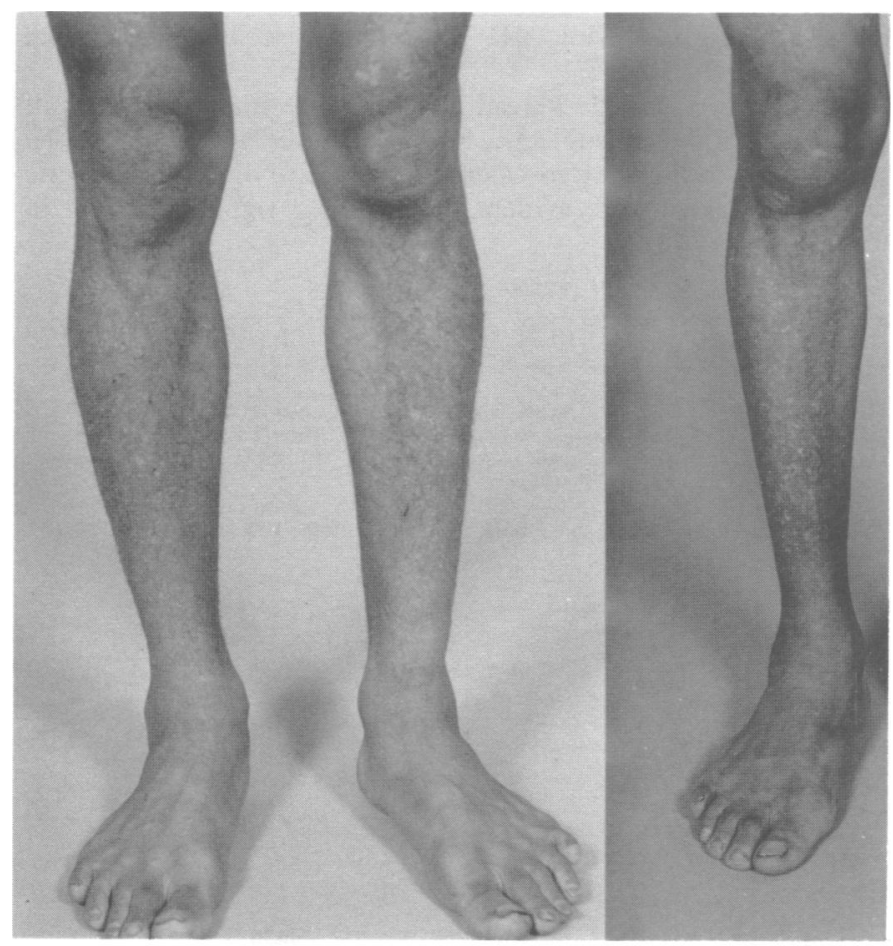

Figure 3 Guttate hypopigmentation on the legs of $(a)$ patient $I I I \cdot 19$ and $(b)$ patient $I I I \cdot 22$.

further clinical evaluation of the eighth family in the series of Sampson et $a l,{ }^{3}$ which showed no linkage to 9q. Phenotypic differences which we document in this article may correlate with the linkage data and provide clinical indicators for the recognition of genetic heterogeneity.

\section{Case reports}

Four affected persons in two generations of a rural
South African family of mixed ancestry were studied (fig 1). Details of the phenotype of each person, as well as a description of one affected member (II 3 ), now dead, are shown in the table. The significant skin lesions, illustrated in figs 2 to 4 are the numerous skin tags at the base of the neck of II 3 III $\cdot 19$, III $\cdot 21$, and III 22 , as well as the whorled pattern of confetti-like depigmentation on the limbs of the two young men. Periungual fibromata were absent in all affected subjects. 


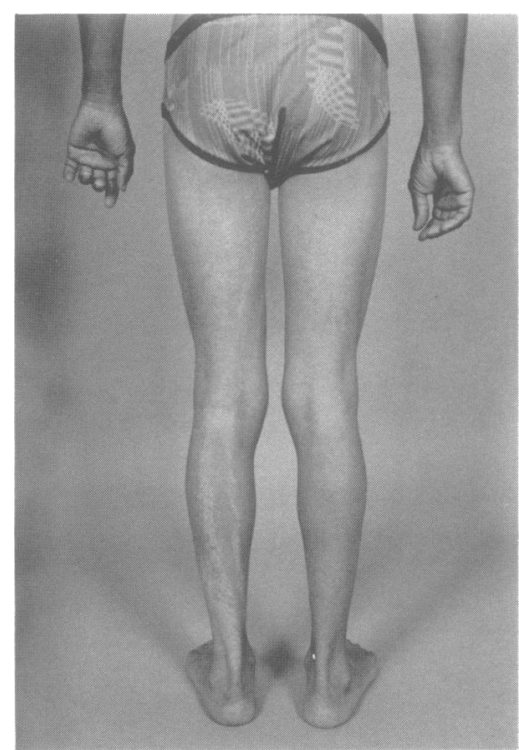

Figure 4 A whorled pattern of confetti depigmentation and a café au lait macule on the leg of patient $I I I \cdot 19$.
Histological examination was undertaken on skin lesions from III $\cdot 19$ and III $\cdot 21$, using standard fixation and haematoxylin and eosin stains. The ash leaf spot and shagreen patch biopsied from III-21 showed the characteristic histological changes, as did the adenoma sebaceum and café au lait macule of III· 19. Sections of skin from the whorls of confetti depigmentation on the leg of III-19 showed reduction in pigment in the basal melanocyte layer. The skin tag excised from the neck of III-19 contained papillomatous lesions lined by unremarkable epidermis. The soft tissue core was mildly oedematous with slight prominence of vascularity. Delicate collagen fibrils produced a glial appearance, suggestive of adenoma sebaceum.

Indirect ophthalmoscopy showed an infratemporal phakoma in the fundus of III $\cdot 19$. III 21 and IV 9 had an identical pattern of unilateral patchy atrophy of the retina, while III. 22 had diffuse bilateral retinal atrophy.

Limited sketelal surveys were undertaken on all affected subjects. Radiographs of the skull of the adults showed calcification typical of TSC. Sclerotic areas were evident on the third right metatarsal of

Phenotypic features of the four affected family members and description of patient $I I \cdot 3$, now dead.

\begin{tabular}{|c|c|c|c|c|c|}
\hline & II $\cdot 3$ & III $\cdot 19$ & III $\cdot 21$ & III $\cdot 22$ & IV $\cdot 9$ \\
\hline $\begin{array}{l}\text { Skin } \\
\text { Adenoma sebaceum } \\
\text { Shagreen patch } \\
\text { Ash leaf macules } \\
\text { Periungual fibromata } \\
\text { Café au lait macules } \\
\text { Acrochordons } \\
\text { Confetti } \\
\text { depigmentation } \\
\text { Whorled } \\
\text { depigmentation }\end{array}$ & $\begin{array}{c}\text { Centrofacial } \\
\text { Low back } \\
- \\
\overline{-} \\
\text { Multiple, base neck* } \\
\text { Arms, legs* } \\
-\end{array}$ & $\begin{array}{c}\text { Centrofacial } \\
3, \overline{-} \\
\text { Multiple } \\
\text { Multiple, base neck* } \\
\text { Legs* } \\
\text { Legs }\end{array}$ & $\begin{array}{c}\text { Centrofacial } \\
\text { Small, low back } \\
\text { Multiple, arms, legs, back } \\
- \\
\text { 4, base neck } \\
- \\
-\end{array}$ & $\begin{array}{c}\text { Centrofacial } \\
\text { 2, low back } \\
\text { Multiple } \\
- \\
\text { Multiple, base neck" } \\
\text { Legs" } \\
\text { - }\end{array}$ & $\begin{array}{c}\text { Centrofacial } \\
\text { Multiple } \\
\text { - } \\
\text { - } \\
- \\
-\end{array}$ \\
\hline $\begin{array}{l}\text { Renal } \\
\text { Symptoms } \\
\text { Angiomyolipomata } \\
\text { Cysts }\end{array}$ & $\begin{array}{l}\text { Unknown } \\
\text { Unknown } \\
\text { Unknown }\end{array}$ & Bilateral & E & Right interpolar & E \\
\hline $\begin{array}{l}\text { CNS } \\
\text { Epilepsy } \\
\text { Mental retardation } \\
\text { CT scan }\end{array}$ & $\begin{array}{l}\text { Grand mal } \\
\text { Unknown }\end{array}$ & $\overline{\overline{S C P}}$ & $\overline{\overline{S C P}}$ & $\begin{array}{l}\text { Petit mal } \\
\text { Severe } \\
\text { SCP }\end{array}$ & $\overline{\overline{S C P}}$ \\
\hline $\begin{array}{l}\text { Dentition } \\
\text { Pitting }\end{array}$ & Unknown & Slight & - & Slight & - \\
\hline $\begin{array}{l}\text { Ophthalmological } \\
\text { Astrocytoma } \\
\text { Retinal atrophy }\end{array}$ & $\begin{array}{l}\text { Unknown } \\
\text { Unknown }\end{array}$ & Right intratemporal & Patchy, right eye & Diffuse, bilateral & $\begin{array}{l}\text { Patchy, } \\
\text { right eye }\end{array}$ \\
\hline Other & - & $\begin{array}{l}\text { Right traumatic retinal } \\
\text { detachment }\end{array}$ & - & - & - \\
\hline $\begin{array}{l}\text { Skeletal } \\
\text { Skull } \\
\text { Hands }\end{array}$ & $\begin{array}{l}\text { Unknown } \\
-\end{array}$ & $\begin{array}{l}\text { Calcification } \\
\text { Mild cortical thickening } \\
\text { middle phalanges }\end{array}$ & $\begin{array}{l}\text { Calcification } \\
-\end{array}$ & Calcification & $\begin{array}{l}\text { Calcification } \\
-\end{array}$ \\
\hline Feet & - & $\begin{array}{c}\text { Sclerotic area L 1st } \\
\text { metatarsal }\end{array}$ & - & - & $\begin{array}{l}\text { Sclerotic } \\
\text { area }\end{array}$ \\
\hline Pelvis & - & - & - & - & - \\
\hline
\end{tabular}

*Denotes unusual features.

SPC=subependymal paraventricular calcification. 
IV 9 and cortical thickening of the first left metatarsal and the middle phalanges of both hands of III 19 .

Ultrasonic scan of the kidneys undertaken in III $\cdot 19$ and III $\cdot 22$ showed hyperechoic masses consistent with the angiomyolipomata of TSC. No renal cysts were identified. CT scan of the skull showed multiple foci of subependymal and paraventricular calcification in all affected subjects.

\section{Discussion}

Many of the features in this family were entirely typical of TSC, but the affected subjects were unusual by virtue of multiple nuchal skin tags and guttate depigmentation of the skin of the legs.

Acrochordons, or skin tags, are not uncommon in the general population. They may be multiple and small on the neck and axillae, or larger, solitary, pedunculated growths on the lower trunk. Multiple tags are often associated with obesity; histologically identical $\operatorname{tags}^{1}$ are also a consistent feature of Gardner's and Cowden's syndromes.

The histological examination of small skin tags shows papillomatosis, hyperkeratosis, and irregular acanthosis with occasional horn cysts. The larger lesions have less marked epidermal changes; the connective tissue stalk is composed of loose collagen fibres and may contain dilated capillaries filled with erythrocytes.

Multiple skin tags have been reported in TSC. ${ }^{5} \mathrm{~A}$ study of 29 affected persons ${ }^{5}$ described nuchal acrochordons in 'a few' of these subjects. In a study of 103 affected persons, ${ }^{6} 19$ adult patients $(18 \cdot 4 \%)$ had soft fibrous tags on the neck, axillae, and eyelids. The histological changes noted in these lesions were of an angiofibromatous appearance with increased cellularity, resembling the facial lesions of the patients studied. Of the 25 persons studied in an earlier survey of TSC in the Western Cape region of South Africa, ${ }^{7}$ where the family reported reside, no mention is made of skin tags.

The nuchal distribution of numerous acrochordons in three family members in this study was notable. A fourth subject (III-21) had only four fibrous tags; she described spontaneous regression of several other such lesions.

The histological changes were those of adenoma sebaceum, as was the case in the previous report ${ }^{5}$ and quite unlike the simple acrochordon unassociated with genetic disorders. It is of interest that in his monograph on TSC, Gomez describes the skin tags of TSC as histologically indistinct from those in the general population or those associated with Cowden's or Gardner's syndromes. They do differ, however, from the cutaneous neurofibromas of neurofibromatosis. Further studies are warranted to elucidate fully the histology of the tags of TSC.

Guttate or speckled hypopigmentation is occasionally seen in normal adults. Butterworth ${ }^{8}$ reported a single case of this white 'freckling', suggesting that this may be a feature of TSC. A comprehensive survey of 23 affected persons recorded three with a confettilike hypopigmentation of the legs. ${ }^{9}$ No affected persons showed these pigmentary changes in either the early study of 103 patients ${ }^{6}$ nor in the earlier South African study. ${ }^{7}$

More striking than the morphology of the confettilike lesions was the whorled patterning of this pigmentary loss (fig 4) reminiscent of the lesions of hypomelanosis of Ito. To the best of our knowledge this streaked patterning of hypopigmentation has not previously been described in TSC.

In conclusion, two unusual clinical features of TSC have been observed in a family in whom the gene for TSC is not linked to $9 q 34$. Further linkage analysis is under way in search of an alternative locus for TSC. We submit that detailed documentation of clinical stigmata in affected families may yield important pointers in the recognition of genetic heterogeneity.

We thank Professor L Handler, Professor B Cremin, and $\mathrm{Dr} \mathrm{K}$ Stoner for radiographical investigation. We are grateful to Elaine Lavin and Gillian Shapley for preparing the manuscript and Sister Luzanne Boyes for drawing the pedigree. Our investigation was supported by the Medical Research Council, the Harry Crossley Foundation, the Mauerberger Fund, and the University of Cape Town Staff Research Fund.

1 Gomez MR. Tuberous sclerosis. 2nd ed. New York: Raven Press, 1988.

2 Fryer AE, Chalmers A, Connor JM, et al. Evidence that the gene for tuberous sclerosis is on chromosome 9. Lancet 1987; $\mathrm{i}$ : 659-61.

3 Sampson JR, Yates JRW, Pirrit LA, et al. Evidence for genetic heterogeneity in tuberous sclerosis. $\mathcal{J}$ Med Genet 1989;26: $511-6$.

4 Smith M, Dumars K, Baumann R, et al. Human Gene Mapping 10. A2038. Cytogenet Cell Genet (in press).

5 Critchley M, Earl CJC. Tuberous sclerosis and allied conditions. Brain 1932;55:311-46.

6 Nickel WR, Reed WB. Tuberous sclerosis. Arch Dermatol 1962;85:209-24.

7 Cornell J. Tuberous sclerosis: clinical manifestations and genetic implications. S Afr Med F 1983;63:966-8.

8 Butterworth T. Discussion of case. Hambrick GW Jr, Brown AC. Tuberous sclerosis with adenoma sebaceum of skin, mucous membrane lesions and epithelial nevus. Arch Dermatol 1968; 97:206.

9 Hurwitz S, Braverman IM. White spots in tuberous sclerosis. $\mathcal{J}$ Pediatr 1970;77:587-94. 